\title{
Agricultural economic development at the rural-urban interface: Community organization, policy, and agricultural change
}

\author{
Jeff S. Sharp ${ }^{a}$, Doug Jackson-Smith ${ }^{\mathrm{b}}$, and Leah Smith ${ }^{\mathrm{c}}$
}

Submitted 3 December 2010 / Accepted 28 April 2011 / Published online 28 June 2011

Citation: Sharp, J. S., \& Jackson-Smith, D., \& Smith, L. (2011). Agricultural economic development at the rural-urban interface: Community organization, policy, and agricultural change. Journal of Agriculture, Food Systems, and Community Development, 1(4), $189-204$. http://dx.doi.org/10.5304/jafscd.2011.014.002

Copyright (C) 2011 by New Leaf Associates, Inc.

\begin{abstract}
Utilizing data from a survey of key informants from U.S. counties at the rural-urban interface (RUI) with substantial agricultural production, this paper explores the relationship between the existence of formal organizations focused on agricultural economic development or food policy and the existence of other types of farm business

${ }^{a}$ Corresponding author: Associate Professor of Rural Sociology, School of Environment and Natural Resources, Ohio State University, 320B Kottman Hall, 2021 Coffey Road, Columbus, OH 43202 USA; +1-614-292-9410; sharp.123@,osu.edu

b Dr. Douglas Jackson-Smith, Associate Professor and Director of Graduate Studies in Sociology, Utah State University, 0730 Old Main Hill, Logan, UT 84322-0730 USA; doug.jackson-smith@usu.edu

${ }^{\mathrm{c}}$ Leah Smith, Rural Sociology Program, Ohio State University

This project was supported by the National Research Initiative of the Cooperative State Research, Education and Extension Service, USDA, grant \#2005-35401-15272.
\end{abstract}

or local food-system development programs. The research draws on concepts associated with traditional community-development theory and tests whether there is a relationship between the existence of social organizational capacity and various activities and outcomes. The analysis includes descriptive, bivariate, and multivariate analyses of data from over 500 U.S. counties located at the RUI. We find that counties that have formally organized, such as through the formation of a committee to support agricultural economic development or the formation of a food policy council, also have more agricultural business and local food-system development programs and policies. We also find that the counties with greater formal organizational development in support of agriculture are counties with larger populations, greater rural population densities, and larger numbers of farms compared to counties with less organizational development. We also find that the existence of these organizations is associated with greater optimism about the future of local agricul- 
ture among county key informants. The results suggest that local community development policy in support of agriculture at the RUI is warranted and the findings suggest opportunities for further research.

\section{Keywords}

agricultural economic development, community development, local food systems, rural-urban interface

\section{Introduction and Review of the Literature}

Although farming is often perceived as a rural activity, a significant amount of food production occurs in metropolitan counties or nonmetropolitan counties adjacent to metropolitan areas. In fact, a substantial proportion of U.S. agricultural sales and a great majority of U.S. fruit and vegetable sales occur in metropolitan counties (Thomas \& Howell, 2003). There are unique opportunities associated with farming in these counties, such as easy access to large, urban markets; but there are challenges as well, such as having to contend with large nonfarm populations and development (Sharp \& Smith, 2004; Berry, 1978). Analysis of recent Census of Agriculture data suggests that many farmers are successfully adapting to the opportunities and challenges at the RUI (JacksonSmith \& Sharp, 2008), though the pattern of farm change can vary widely across urbanizing landscapes. In this research we examine the extent to which formal community programs and institutional arrangements designed to support the local farm economy at the RUI are related to the aggregate patterns of change.

While the impact of farming on community quality of life has received considerable academic attention (Goldschmidt, 1978; Lobao \& Stofferahn 2008; Lyson, 2004), the role of communities in supporting local agriculture has received modest attention. ${ }^{1}$

\footnotetext{
${ }^{1}$ It must be noted that the work of Lyson and colleagues (Lyson, 2004; Hinrichs \& Lyson, 2007) provides a starting point for discussing the relationship of communities and agriculture, but that work so far has generally focused on the "civic" contributions of agriculture to the public good and less on the community strategies and policies to foster civic agriculture.
}

Given the public enthusiasm for locally produced foods and the growing interest among local governments and nonprofits in meeting economic and social goals through food-system development, it is necessary to systematically assess the extent to which communities are developing programs to support local agriculture and to identify the preconditions and outcomes of these activities. We approach this project viewing efforts to develop the local food and farming sector as essentially a form of community self-development, in which the community relies on local resources and/or assets to improve its social and economic well-being (Christenson, Fendley, \& Robinson, 1989), and we draw on insights from the community- and selfdevelopment traditions, focusing on the importance of organizational capacity and development programs.

We conduct descriptive, bivariate, and multivariate analysis to explore the relationships among community organizational capacity, development policies and programs, and changes in local agriculture. We first determine the extent to which communities have formally organized themselves to support farming and food system development, and we identify the distinctive characteristics of the places that are most aggressively working to support local agriculture. We then review the incidence of various programs and policies aimed at supporting the viability and development of local agriculture. We anticipate a strong association between social organizational development and the development of specific programs and policies. Finally, we expect that both organizational and programmatic work will impact the structure of local agriculture.

Work such as this is necessary (1) to validate that existing local social organizational and development policy efforts are having an impact and (2) if such an impact is identified, to provide evidence to other communities not currently organized or engaged in development activities that such efforts merit consideration. In addressing these two needs, the results should be of immediate use to practitioners and officials considering or already engaged in food-system development work by validating or inspiring their continued effort. The research also 
contributes to the ongoing scholarly questions related to food-system change, particularly the opening up of a new avenue of inquiry related to the notion of civic agriculture (Lyson, 2004) by being attentive to how communities can contribute to agricultural vitality.

\section{Community Development}

Community development has been defined as "a group of people in a locality initiating a social action process (i.e., planned intervention) to change their economic, social, cultural, and/or environmental situation" (Christensen et al., 1989, p. 14). Explanations of why some communities are able to effectively work together and others are not include the importance of social interactions and local organizational capacity. As a starting point, we acknowledge the insights of interactional field theory, which emphasizes that communities are made up of numerous fields of social interaction that develop over time among local actors (Wilkinson, 1970, 1972). Interactional field theory anticipates that the existence of communityplanning processes, community-oriented leadership, structures, and processes of mobilizing local resources, and organizations with the ability to coordinate local action all can contribute to increased capacity for community action and development.

More contemporary concepts such as social capital or social infrastructure build on the basic premise of interactional field theory. One social capital scholar, Woolcock (1998), argues that people are most powerful when they are connected to others and can inform and assist one another and work together to create change within their communities. Flora and Flora (1993) describe how their awareness of social infrastructure developed from their finding that outstanding leaders from one community were totally ineffective when moved to another. Though the communities were similar in size, physical infrastructure, and economic base, there existed important differences in communitylevel social and organizational characteristics. Based on these insights and a body of supporting research (Putnam, 1993; Flora \& Flora, 1993; Sharp, Agnitsch, Ryan, \& Flora, 2002; Green \&
Haines, 2008), we anticipate that farming and foodsystem development at the community level is enhanced to the extent there exists social institutional and organizational infrastructure that is capable of facilitating these activities.

The literatures on both community development and local food systems identify local organizations as a key element in affecting change. The practice of self-development involves citizen participation, with the assumption that people working together can improve their situations. Through participation, community members develop their own capacity to contribute to community change, learn about issues and alternatives, and become integrated into collective action. Community members who have the opportunity to share their input are more invested in the success of development activities (Green \& Haines, 2008); and social processes that bring people together to discuss concerns can facilitate agreements being reached and plans of action being made and implemented (Littrell \& Hobbs, 1989). Local organizations, then, are a necessary condition for development in that they provide a vehicle for citizen participation (Garkovich, 1989). The community-development literature specifically highlights the importance of umbrella or coordinating organizations that include diverse interests (Sharp, 2001; Littrell \& Hobbs, 1989) and can serve as a social hub in which individual interests are expressed and translated into goals, diverse local resources are identified, and these resources are mobilized to achieve those goals (Garkovich 1989, Green \& Haines, 2008). Organizations also can serve as intermediaries between local citizens and the state, assist in the acquisition and management of state support, and present local demands to outside organizations and bureaucracies. Finally, the existence of diverse community organizations has been found to improve the capacity of communities to access external resources and coordinate the flow of information and resources that support community development (Sharp, 2001).

\section{Food-System Development Capacity}

Approaching local food-system development as a particular variation of community development, we 
anticipate that a community's capacity to develop the local food system is enhanced where the diverse food-system actors in a community are connected via an organization that provides structure for action around common goals. Wright and colleagues (2007, p. 42) explain:

\section{We contend that communities will best be served to withstand economic and social change by becoming proactive and preparing for vigilant engagement through multi- stakeholder collaboration...this approach can allow communities to become 'food system makers' rather than "food system takers" in the new global economy.}

This observation is supported by a study of programs funded by the federal Sustainable Agriculture Research and Education (SARE) program over 10 years in which Feenstra (2002) finds that a key theme running through successful local foodsystem development programs is the ability of community leaders to "create space" for the development of local food-system activities. The kind of spaces that these leaders create include social space for diverse people in the community to come together to get to know each other, as well as space for celebrating and enjoying each other, such as at a fair or festival.

Two prominent examples of local social organizations that facilitate discussions among diverse stakeholders about the future of local agriculture include farm-oriented development committees and food policy councils. In the first instance, many communities have created agriculture-related committees or advisory boards to provide feedback to local governments about the impacts of local policies on farmers and to coordinate efforts to pursue agricultural economic-development and farmland-preservation initiatives in support of local farming (Lyson, 2004). Local agricultural committees have historically focused mainly on the interests and needs of farmers, local agribusinesses, and rural landscapes. By contrast, food policy councils tend to originate in urban areas, with the voices of consumers, environmental groups, and social justice organizations more prominently represented in addition to representation of farmer and agribusiness interests (Clancy, Hammer, \& Lippoldt, 2007).

\section{Farm and Food-System Development Programs and Policies}

Our community-development orientation leads us to further anticipate that the creation of formal institutions or organizations can provide a critical foundation for the development and implementation of effective programs and policies. In this section, we consider the potential significance of these programs and policies for shaping patterns of agricultural change at the RUI.

Programs and policies to support local agricultural and food-system development are generally consistent with the programs and policies associated with other forms of self-development that many rural communities have engaged in over the years. Self-development, in contrast to efforts to recruit extra-local (often industrial-scale) firms, focuses on local economic strengths and often relies on local resources to support the growth and development of local businesses (Blakely, 1994; Flora \& Flora, 2004; Green \& Haines, 2008). Efforts to support and develop local firms has been shown to have meaningful implications for community economic vitality and well-being (Korsching \& Allen, 2004; Muske, Woods, Swinney, \& Khoo, 2007) as the owners of these firms often give back to the community, take leadership roles and tend to be quite civically minded (Muske \& Woods, 2004).

Unfortunately, the food and farming sector has often been overlooked as an economic asset to be developed, with Lyson arguing that "it is time to put agriculture and food on the political agendas of local communities" (2007, p. 29). Lyson further observes that "local agriculture and food businesses need the same access to economic development resources-such as grants, tax incentives, and loans-as nonfarm-related businesses" (p. 30). In many urbanizing communities, though, agricultural economic-development efforts may be perceived as a relic of the localities' rural past rather than a developable asset relevant to its future. Agricultural development may also not have the same allure to 
development professionals as the impact of a successful effort to recruit a new industrial employer capable of creating numerous new jobs in a community.

Nevertheless, there has been growing interest in the economic development potential of agriculture, with a number of emerging programmatic and policy initiatives appearing across the United States (Preston \& Bailey, 2007). Farm-oriented development efforts are being considered in response to the economic downturn that has seen a decline in industrial and construction sectors in some regions. Farm-oriented development to improve agricultural profitability has also been pursued in some places as an effort to enhance farm viability and slow down the conversion of farmland to nonfarm purposes. Such efforts can include general support for local farm businesses (including providing access to business skills training and credit), technical support for business diversification or new enterprise development, and beginning farmer programs designed to facilitate the transfer of family farms across generations (Nelson, Mullan, O’Neill, \& Morse, 2004). Other economic-development projects have involved tax incentives and other initiatives to attract value-added foodprocessing facilities and adjustments to local landuse ordinances to enable farmers to conduct onfarm processing and retailing of their agricultural products (Cowan, 2002). One particular area of food and farming development activity that has received increasing attention are efforts to support the development of "local food systems" (Hinrichs \& Lyson, 2007; Sharp, Clark, Davis, Smith, \& McCutcheon, 2011). Local food-system programs include activities to support direct marketing by local farms (farmers' markets, direct sales to local institutions) and enhancing opportunities for local residents to produce their own food (e.g., community gardens and urban farming ventures).

Recognizing that these various development programs and policies are emerging in some localities, we hypothesize that communities that have developed the social infrastructure or organizational capacity to support food and farm system development will be more likely to enact agricultural economic-development policies and programs as well as local-foods-oriented activities. In turn, we also expect that the existence of these programs and policies will positively affect the viability of local agriculture and other characteristics of farming (such as more farms, more agricultural sales, etc.).

\section{Data and Methods}

As noted in the introduction, our contextual setting of interest is the subset of U.S. counties located at the RUI. We further narrow our attention to focus on those counties at the RUI that generate a substantial amount of agricultural production. The focus on these agriculturally important (AI) counties at the RUI allows us to assess the impact of local organizations and programs across relatively comparable urbanizing landscapes of the United States. Also, during the 2000s, in areas where there is both significant agricultural activity and urban growth, the local farm sector is typically confronted with both challenges (such as competition from nonfarm growth and development) and opportunities (linked to growing urban interest in local and regionally produced foods). Indeed, almost half of all U.S. direct sales of farm products to consumers in 2007 occurred in counties that were both agriculturally important and at the RUI (Porreca, 2010). Thus we expect the incidence of food and farming system development to be substantial and also quite salient in RUI settings, providing an appropriate context for investigating our basic questions.

The data for this analysis comes from the 2008 survey Agricultural Change, Land Use, and Economic Development at the Rural-Urban Interface, a key informant survey of agriculturally important RUI counties in the United States. The survey was funded by the United States Department of Agriculture National Research Initiative (USDANRI). Additional data is drawn from the 1997 and the 2007 USDA-National Agricultural Statistics Service Census of Agriculture (USDA NASS, 2004, 2009) and the 1990 and 2000 United States Census. To identify RUI counties, we utilized the urban influence codes (UIC) developed by the USDA Economic Research Service. These codes classify 
U.S. counties according to whether they are metropolitan or nonmetropolitan, and in the case of nonmetropolitan whether they are adjacent to a metropolitan area. We first focused our attention on U.S. metropolitan counties or nonmetropolitan counties adjacent to large metropolitan areas (UIC codes $1-4$, of which there are 1,267 counties) and some nonmetropolitan counties adjacent to small metropolitan counties (UIC codes 5-7 that experienced population growth above the national average of $13.15 \%$ between 1990 and 2000, of which there are 255 additional counties). ${ }^{2}$ From this set of counties, we then focused on the subset of RUI counties that are agriculturally important, defined as being in the top quartile of U.S. counties ranked by farm sales in 1997 (Jackson-Smith \& Jensen, 2009). ${ }^{3}$ The $40 \%$ of all RUI counties that are agriculturally important account for almost $80 \%$ of the agricultural production occurring at the RUI (Jackson-Smith \& Sharp, 2008).

We then conducted a survey of key informants in each of these 619 counties. We focus on counties as our unit of analysis, due in part to the fact that counties are generally the unit of government across the United States that has responsibility for agricultural land use and also often plays an important role in rural economic development. ${ }^{4}$ We also focused on the county as a unit of analysis because extensive Census of Agriculture data is reported for this geographic unit. To acquire additional information about counties, a key informant survey is an effective strategy for eliciting factual information about a county. Because one informant might have limited knowledge about some

\footnotetext{
${ }^{2}$ UIC codes are developed by the USDA-ERS and can be accessed online at http://www.ers.usda.gov/Briefing/ Rurality/urbaninf/

${ }^{3}$ See Clark (2009) for a more detailed discussion of the methods used to identify agriculturally important counties.

${ }^{4}$ We know that in some states, other units of local government wield important power (such as the power Michigan townships have over land use), but even in this context counties remain an important entity in regards to agricultural development and change. Still, future research should be attentive to the development role of subcounty units of government as well as state governments, which are not addressed in this research.
}

aspects of the community or county, we sought information from several key informants. The key informants from each county were identified through web-based research of county institutions and telephone surveys of county extension or local government staff. We purposefully sought to identify informants from different institutional backgrounds to maximize the likelihood that accurate community information was acquired. The final sample included five key informants from each of the counties, although a couple counties had fewer, due to the absence of the desired informant in the community. A key informant from each of the following classes of individuals was surveyed in each county:

- a local government official familiar with local land-use planning and policies;

- an economic-development professional or business leader familiar with economicdevelopment efforts related to agricultural development programs;

- a natural resource professional familiar with farmland preservation, conservation, and management;

- an agricultural professional, such as the county agricultural extension agent; and

- an agricultural organization representative, such as a county Farm Bureau president or other agricultural leader familiar with local challenges to farmers and adaptive strategies in response to these challenges.

The survey of the sample of key informants was conducted in winter 2008. The Tailored Design Method (Dillman, 2007) guided the data collection process. The sampled respondents received a prenotification letter, a cover letter and survey instrument, a reminder postcard, and a replacement survey when necessary (including surveys to potentially new respondents nominated in surveys returned from the initial mailing). A total of 1,938 useable surveys from a total of 619 counties were ultimately received, with at least one informant replying from each of the counties surveyed and an average of three informants per county. Responses 
from key informants from the same county were aggregated to create a county-level attribute (Krannich \& Humphrey, 1986). For questions involving facts, such as, "Does policy A exist in the county?" the modal response of all respondents from that county was used. With questions of a more subjective nature, the mean response of all respondents from the county was utilized.

One final note regarding the sample is the discovery of a number of influential data points and/or outliers during our evaluation of the data that led us to exclude several counties from our final analysis. Data from these counties were excluded because their values for certain variables of interest are so exceptional when compared to most other counties that they adversely impact our statistical analysis and our ability to understand the relationships of interest. Specifically, California counties were excluded from the analysis due to agricultural and demographic statistics for these counties being substantially larger than nearly every other U.S. county. ${ }^{5}$ In addition, two Arizona counties (Navajo and Maricopa) were excluded due to influential data points that likely arise from changes in how official population or agricultural data for these counties have been enumerated across time.

\section{Measures of Key Concepts}

We now turn our attention to how key variables and concepts were measured in the survey and/or operationalized for this analysis. To measure the level of community organizational development around the food and farming system, we utilized responses from two survey questions. One question measured whether the county had formed a committee or group to promote the viability of agriculture, and another question assessed whether citizens of the county had formed a food policy council or other program aimed at tackling issues of nutrition, hunger, and/or food access. These reflect two common organizational structures that

\footnotetext{
${ }^{5}$ We recognize that California is an important situation that warrants full consideration and recommend that Californiaspecific case study research may be a more appropriate approach to considering our questions in regard to that context.
}

have been used to develop and enact policies in support of local food and farm systems. The responses to these two questions concerning organizations were combined into a scale with three discrete categories. The county might have reported no organizational development around farming and the food system (labeled None in our tables), there might be one or the other type of organization (Moderate Organization), or both a committee or group working to promote the viability of agriculture and a food policy council existed in the community (Advanced Organization).

Key informants were also asked questions related to the existence of a wide range of local farm and food policies and programs. These policies and programs were generally of two types. The first includes general policies in support of local farming enterprises and value-added processing that are designed to encourage the viability of local farms and to promote local economic development activities. In our analysis, we utilized measures of the following agricultural economic-development activities: (a) business planning training for local farmers, (b) promotion of crop diversification or use of alternative production practices, (c) efforts to facilitate access to credit by local farms, (d) support for beginning farmers, (e) development of locally owned, value-added processing facilities, and $(f)$ amendment of local ordinances to facilitate on-farm processing or sales. These six items were also summed to create a Farm Business Development scale reflecting the amount of local agricultural economic-development activity in each study county.

The second type of food-system development activities consists of programs and policies specifically designed to facilitate the emergence of "local food systems" in which local consumers are provided with greater opportunities to purchase food from local farmers. In the analysis below, we utilize indicators of the presence of the following types of local foods initiatives: (a) programs to promote direct marketing of local food products, (b) publication of a directory of local food suppliers, (c) programs that promote agritourism, and (d) efforts to develop marketing labels that identify 
locally grown foods. A Local Food System Development scale was created from these items to reflect the relative amount of this type of programmatic activity in each study county.

\section{Results}

\section{Level of Food and Farm-Oriented Social Organization}

The results of the key informant survey across our sample of AI/RUI counties reveal that nearly $76 \%$ have a committee to support the viability of agriculture, while nearly $42 \%$ have organized a food policy council or similar organization (see table 1). This pattern suggests that food policy councils may be a more advanced form of food system organizational development, although we note that the incidence of food policy councils was higher than we expected and that the policy council indicator may reflect informants' awareness of policyoriented organizational development, but not necessarily instances of food policy councils as

\section{Table 1. Organizations and Organizational Development in Study Counties $(N=512)$}

\begin{tabular}{lc}
\hline Organization & $\begin{array}{c}\% \text { of } \\
\text { counties }\end{array}$ \\
\hline $\begin{array}{l}\text { Type of organization in the county } \\
\quad \text { Committee to support the viability of } \\
\quad \text { agriculture }\end{array}$ & $75.8 \%$ \\
$\quad$ Food Policy Council & $41.8 \%$ \\
\hline $\begin{array}{l}\text { Level of organizational development in the } \\
\text { county }\end{array}$ & \\
$\quad$ No organizations & $18.6 \%$ \\
$\quad$ Moderate (1) organization & $45.3 \%$ \\
$\quad$ Advanced (2) organizations & $36.1 \%$ \\
\hline
\end{tabular}

Table 2. Population Demographics by Level of Organization $(N=512)$

\begin{tabular}{lccc}
\hline & None & Moderate & Advanced \\
\hline Total population (2000) & 115,132 & 190,670 & $254,489 *$ \\
Population density (per/sq. mile) (2000) & 201 & 184 & $310^{*}$ \\
Rural population density (2000) & 53 & 57 & $67 *$ \\
Population change, 1990-2000 (\%) & $21.6 \%$ & $17.7 \%$ & $16.4 \% *$ \\
Net population change, 1990-2000 & 18,102 & 16,135 & $27,903 *$ \\
\hline
\end{tabular}

* F-test significant at .05 level formally described in the local food systems literature (e.g., Clancy et al., 2007). Of the 512 counties for which we received complete data, $18.6 \%$ reported having neither organization, $45.3 \%$ reported one organization working on farming and food system issues, and $36.1 \%$ have both (see table 1). The pattern of agricultural viability organizations being more common and food-policyoriented development being less common is consistent with our own investigation of RUI counties in recent years (Clark, Inwood, Sharp, \& JacksonSmith, 2010).

Given the pattern of some counties being more formally organized versus some being less formally organized, we examined how population demographics, farming and food system development, and agricultural structure vary by each of the levels of organization in each county.

\section{Population Demographics by Level of Organization} We first considered the extent to which basic population demographics vary by level of social organization. Recall that our sample is composed of counties located at the RUI, so it is quite likely that nonfarm population growth can be a factor in local planning and development policy related to agriculture. Our analysis reveals an association between level of organizational development and population characteristics, with more populous and more densely populated RUI counties reporting more organizational development when compared to less populated counties (table 2). Higher rural population densities (measured as persons per square mile in unincorporated areas, or outside of incorporated municipalities in a county) were also associated with more advanced levels of organizational development. Also, the rate of population growth tended to be higher in the less organized counties. However, their higher rate was largely a function of their smaller initial size. Net population change between 1990 and 2000 was higher in counties with more advanced organizational development. 
Social Organizational Capacity and Agricultural

Development and Food System Policies and Programs

We next explore the association between the presence of social organizations and the enactment of farm business development or local food-system development programs and policies. Looking first at the farm business development activity, table 3, we find that the most common activities in $\mathrm{AI} /$ RUI counties are programs related to business planning, crop diversification, and enhancing access to farm financing. Moreover, there is a positive relationship between the existence of farm- and food-oriented social organizations and the presence of these types of agricultural development activity. Generally speaking, about $80 \%$ of the counties with some organizational development reported these activities, while only two-thirds of counties with no organizational development reported these types of development activities. Programs to support beginning farmers were also quite common in counties with more advanced organizational development ( $83 \%$ of counties) and less common in moderately organized counties $(69 \%)$. Just less than half the counties with no formal organizations reported these sorts of programs.

Efforts to develop locally owned processing facili- ties and where local land-use ordinances had been amended to facilitate on-farm processing or sales were most common in counties with advanced organizational development, but at noticeably lower frequency than was the case with more business- and finance-oriented activities. Relatively few of the counties with no organizational developments reported that there had been efforts to develop value-added processing or ordinance amendments.

Looking at the Farm Business Development Scale (a count of the presence of these six farm business development programs and policies), we find that counties with more advanced levels of social organizational development reported more farm business development activities (4.6 on average). Counties with moderate organizational development reported an average of 3.9 activities. The counties with neither organization reported an average of 2.8 activities.

Due to their proximity to larger urbanized areas as well as relatively large local populations of their own, we anticipated there would be substantial local food-system development activity in our RUI study counties. Data for the Local Food System Development Scale and associated sub-items are

Table 3. Farm Business Development Activity by Level of Organization $(N=512)$

\begin{tabular}{|c|c|c|c|c|}
\hline \multirow[b]{3}{*}{ Farm Business Development Scale } & All counties & None & Moderate & Advanced \\
\hline & \multicolumn{4}{|c|}{ Mean } \\
\hline & 3.9 & 2.8 & 3.9 & $4.6 * *$ \\
\hline Specific Activities & \multicolumn{4}{|c|}{ Percentage } \\
\hline $\begin{array}{l}\text { A course or program that provides training in business } \\
\text { planning for county farmers or ranchers }\end{array}$ & $87.4 \%$ & $74.2 \%$ & $87.0 \%$ & $94.5 \% *$ \\
\hline $\begin{array}{l}\text { Program to promote crop diversification or alternative } \\
\text { production techniques }\end{array}$ & $83.4 \%$ & $61.7 \%$ & $84.7 \%$ & $92.9 \% *$ \\
\hline $\begin{array}{l}\text { Program facilitating access to public or private credit for } \\
\text { farmers or ranchers }\end{array}$ & $78.2 \%$ & $62.9 \%$ & $78.3 \%$ & $85.6 \% *$ \\
\hline Program to support beginning farmers & $70.1 \%$ & $47.4 \%$ & $69.4 \%$ & $82.7 \% *$ \\
\hline $\begin{array}{l}\text { Successful effort to develop a locally owned, value-added } \\
\text { processing facility }\end{array}$ & $45.9 \%$ & $20.2 \%$ & $45.2 \%$ & $59.8 \%$ * \\
\hline $\begin{array}{l}\text { Amendment of local ordinances to facilitate on-farm } \\
\text { processing or sales }\end{array}$ & $34.5 \%$ & $15.8 \%$ & $32.3 \%$ & $47.4 \%$ * \\
\hline
\end{tabular}

*chi-square significant at .05 level, **F-test significant at .05 level 
Table 4. Local Food System Development Activity by Level of Organization

\begin{tabular}{|c|c|c|c|c|}
\hline & All Counties & None & Moderate & Advanced \\
\hline Local Food Development Activity Scale (mean) & 3.0 & 2.0 & 2.8 & $3.6 * *$ \\
\hline Specific Activities & \multicolumn{2}{|c|}{$\%$} & \multicolumn{2}{|c|}{$\%$ of counties } \\
\hline $\begin{array}{l}\text { Program to promote direct marketing of local food products in } \\
\text { the county }\end{array}$ & $86.1 \%$ & $68.4 \%$ & $84.1 \%$ & $97.8 \% *$ \\
\hline Program or event to promote agritourism opportunities & $76.3 \%$ & $53.7 \%$ & $74.19 \%$ & $90.8 \%$ * \\
\hline $\begin{array}{l}\text { Published directory of local food producers, retailers, or } \\
\text { farmers' markets }\end{array}$ & $72.5 \%$ & $43.6 \%$ & $68.8 \%$ & $91.8 \% *$ \\
\hline $\begin{array}{l}\text { Promotion of local/homegrown food product labels and } \\
\text { campaigns }\end{array}$ & $61.2 \%$ & $37.9 \%$ & $52.4 \%$ & $84.2 \%$ * \\
\hline
\end{tabular}

*chi-square significant at .05 level, **F-test significant at .05 level

reported in table 4, along with comparisons of the use of these activities by level of county organizational development. Local food system policies and programs were reported in most AI/RUI counties, although the counties that reported more formal organizational development were much more likely to report local foodsystem development activity than counties with less development.

Table 5. Influences on Agricultural and Local Food Development Activity

\begin{tabular}{|c|c|c|}
\hline & $\begin{array}{l}\text { Agricultural Business } \\
\text { Development Activity } \\
\text { (scale) }\end{array}$ & $\begin{array}{l}\text { Local Food } \\
\text { Development Activity } \\
\text { (scale) }\end{array}$ \\
\hline & \multicolumn{2}{|c|}{ Standardized Coefficient } \\
\hline Rural population density (2000) & -.04 & $.16 *$ \\
\hline Net population change, $1990-2000$ & -.04 & -.01 \\
\hline Farms, 1997 & .08 & $.17 *$ \\
\hline Agricultural sales, 1997 & $.09 *$ & .01 \\
\hline \multicolumn{3}{|l|}{ Level of organizational development ${ }^{a}$} \\
\hline Moderate organizational development & $.35 *$ & $.28 *$ \\
\hline Advanced organizational development & $.54 *$ & $.58 *$ \\
\hline F-test & $21.09 *$ & $34.66 *$ \\
\hline Adj. R-square & .19 & .28 \\
\hline
\end{tabular}

* significant at .05 level, a Reference group is none.

In counties that had established committees to promote local farming and created food policy councils, over $90 \%$ reported the presence of programs to promote direct marketing, publication of local food directories, and programs to promote agritourism. The promotion of a local label or campaign was quite common in the most organized counties; it sometimes occurred in the moderately organized counties; and it was much less common in the counties with no organizational development.

In terms of the Local Food Development Activity Scale (which summarizes the existences of these various programs in a county, with the scale ran- ging from 0 to 4 ), the most organized counties reported an average of 3.6 of the activities, while 2.8 of the activities were reported on average in the counties with moderate levels of organizational development. The counties with little organizational development reported an average of only 2 of the activities.

To arrive at a more nuanced analysis of the relationship between organizational development and the existence of agriculture-oriented local policies and programs, we conducted a series of multivariate analyses (results are reported in table 5). ${ }^{6}$ Both

\footnotetext{
${ }^{6}$ In these models, we control for important demographic and farm-sector characteristics and examine whether the presence
} 
regression models find that development of social organizations around farm and food issues is a strong predictor of the emergence of local farm and food policies and programs. We find that counties with moderate and advanced organizational development also report more agricultural business development activity and local food development activity compared to communities that report no organizational development. We also find that local food development activity is more likely in counties with high rural population densities and where there are more farms. In other words, a high density of both farms and rural residents appears to be more conducive to the emergence of local food development activities. We find that higher rural population densities and the existence of more farms is not related to agricultural business development activity (see table 5).

\section{Organizational Capacity and Local Farm Conditions} Community organizations to promote local agriculture and food systems are created not only to facilitate development of programs and activities, but ultimately to enhance prospects for local farmers, stimulate local agricultural economic activity, and protect against farmland loss. Because our data reflect a cross-sectional snapshot of conditions in each county in 2008 , it is impossible to prove whether forming these organizations causes different changes in farm and food system outcomes. However, distinctive patterns of association between the presence of local organizational development and certain indicators of farm-sector conditions can provide insights into the characteristics of places most likely to adopt these strategies,

or absence of social organizations to promote farm and food initiatives is associated with the development and implementation of agricultural economic and local food system policies and programs. We include rural population density and net population change in these models because we anticipate both might adversely impact agricultural outcomes (such as growth in the sector). From the Census of Agriculture, we include measures of the number of farms and the total agricultural sales in a county as reported in 1997. We include these items because we appreciate that those counties with large agricultural sectors may be better positioned to sustain a critical mass of production across time that allows the sector to remain vibrant and may mitigate some of the nonfarm population pressures. as well as tentative evidence of their impacts on the health of the local farm and food sector.

A comparison of farm-sector characteristics and trends from the 1997 and 2007 Censuses of Agriculture (table 6) by level of organizational development suggest some interesting relationships between the level of organizational development and farm-sector conditions. Generally speaking, the more organizationally developed counties tend to have larger agricultural sectors (in terms of total farm numbers and total agricultural sales). Interestingly, there is no difference among the different groups of counties in terms of the rate of change in number of farms or change in agricultural sales between 1997 and 2007. This suggests that organizational development over the previous decade did not systematically affect the pace and direction of changes in the size or structure of the local farm sector (or that rates of farm change were not systematically related to the emergence of these organizations). Meanwhile, average sales per farm and the rate of change in sales per farm were similar across farms in all three sets of counties.

One major goal of local farm and food organizations is to promote greater sales of locally produced farm products within the community. In the most organizationally advanced counties, the number of farms with sales direct to consumers was considerably higher than in the counties with less organizational development. The total amount of direct farm sales in the most organizationally advanced counties was over US $\$ 1.2$ million in 2007 , nearly double the level in the moderately advanced counties, and three times the level in the counties with the least organizational development. A surprising result was that counties with greater organizational development had lower growth rates in the numbers of farms with direct sales and the total volume of direct sales. To some extent, lower growth rates might reflect the fact that the counties without these organizations had much lower initial levels of direct sales and thus a greater statistical tendency for high rates of growth (relative to places that had high initial levels of direct sales). 
Table 6. Current Status and Rates of Change in Local Farm Sector by Level of Organization

\begin{tabular}{|c|c|c|c|}
\hline & None & Moderate & Advanced \\
\hline Farms, 1997 & 855 & 1,025 & $1,121 *$ \\
\hline Farms, 2007 & 864 & 1,004 & $1,104 *$ \\
\hline$\Delta$ Farms, 1997-2007 (\%) & $-0.1 \%$ & $-1.8 \%$ & $-1.7 \%$ \\
\hline Ag. sales, 1997 (US\$ million) & 94.8 & 108.4 & $125.5^{*}$ \\
\hline Ag. sales, 2007 (US\$ million) & 136.2 & 160.0 & $181.4 *$ \\
\hline$\Delta$ Ag. sales, 1997-2007 (\%) & $49.6 \%$ & $48.3 \%$ & $48.9 \%$ \\
\hline Average sales per farm, 1997 (US\$) & 128,969 & 122,553 & 117,157 \\
\hline Average sales per farm, 2007 (US\$) & 185,729 & 187,423 & 179,225 \\
\hline$\Delta$ Sales per farm, 1997-2007 (\%) & $49.9 \%$ & $51.9 \%$ & $52.7 \%$ \\
\hline \multicolumn{4}{|l|}{ Direct Farm Sales to Consumers ${ }^{1}$} \\
\hline Farms with direct sales, 2007 & 52 & 75 & $104 *$ \\
\hline$\Delta$ Farms with direct sales, $1997-07$ & 34.5 & 22.5 & $23.1^{*}$ \\
\hline Total direct sales dollars, 2007 (US\$) & 410,000 & 677,050 & $1,249,700 *$ \\
\hline$\Delta$ Direct sales, 2002-07 (\%) & $182 \%$ & $100 \%$ & $110 \% *$ \\
\hline
\end{tabular}

Tests of statistical significance from ANOVA F-test ( $*=$ signif. at .05 level) ${ }^{1}$ Direct farm sales reflect sales direct to consumers by the farm producer and have been collected as a specific category of sales by the U.S. Census of Agriculture since 1992.

\section{Table 7. Policy Impacts and Perceived Optimism by Level of Organizational Development}

\begin{tabular}{|c|c|c|c|}
\hline & \multicolumn{3}{|c|}{ Level of Organizational Development ${ }^{a}$ (mean) } \\
\hline & None & Moderate & Advanced \\
\hline Policies keep land in this county in farming or agricultural uses & 3.1 & 3.3 & $3.6^{*}$ \\
\hline Policies maintain the viability of farms in this county & 3.2 & 3.4 & $3.6^{*}$ \\
\hline Policies enable new farms to get started in this county & 2.8 & 3.0 & $3.1 *$ \\
\hline Optimism/pessimism about the future of agriculture in this county? & 4.1 & 4.5 & $4.6 *$ \\
\hline
\end{tabular}

a Reference group is none.

Another possible measure of the impact of organizational development is reflected in more subjective assessments of the key informants concerning their perceptions of the impacts of

local organizations and policies on local farm viability and farm-sector conditions. Specifically, informants were asked the extent to which agricultural economic development programs and policies had affected "keeping land in this county in farming or agricultural uses," "maintaining the viability of farms in this county," and "enabling new farms to get started in this county." Response categories ranged from a strong positive impact (coded 5) to a strong negative impact (coded 1), with the middle category (3) being no or mixed impact. A comparison of mean scores on these items by level of organizational development is shown in table 7 . The results suggest that key actors in counties with more organizational development have more positive impressions of the impact of local efforts across all three measures. A final question was asked of key informants: "using a scale of 1 to 7 (where 1 is 
Table 8. Subjective and Objective Assessments of Agricultural Change

\begin{tabular}{|c|c|c|c|c|}
\hline & $\begin{array}{c}\text { Policies } \\
\text { Keep Land } \\
\text { in Farming }\end{array}$ & $\begin{array}{c}\text { Policies } \\
\text { Maintain Farm } \\
\text { Viability }\end{array}$ & $\begin{array}{c}\text { Policies } \\
\text { Enable New } \\
\text { Farms To Start }\end{array}$ & $\begin{array}{l}\text { Optimistic } \\
\text { About Future } \\
\text { of Agriculture }\end{array}$ \\
\hline & \multicolumn{4}{|c|}{ Standardized Regression Coefficients } \\
\hline Rural population density (2000) & -.04 & $-.13 *$ & $-.12 *$ & $-.14 *$ \\
\hline Net population change, $1990-2000$ & $-.13^{*}$ & $-.13 *$ & $-.13 *$ & $-.26 *$ \\
\hline Farms, 1997 & -.08 & $-.10 *$ & -.05 & -.04 \\
\hline Agricultural sales, 1997 & .06 & $.12 *$ & .04 & $.14 *$ \\
\hline Agricultural business development activity & $.25^{*}$ & $.28 *$ & $.29 *$ & $.19 *$ \\
\hline Local food development activity & -.05 & -.08 & -.08 & -.07 \\
\hline \multicolumn{5}{|l|}{ Level of organization development ${ }^{a}$} \\
\hline Moderate organizational development & .08 & .10 & .04 & .08 \\
\hline Advanced organizational development & $.25 *$ & $.19 *$ & $.16 *$ & .10 \\
\hline F-test & $11.01 *$ & 12.34 & $10.79 *$ & 12.86 \\
\hline Adj. R-square & .14 & .15 & .13 & .16 \\
\hline
\end{tabular}

*F-test significant at .05 level. a Reference group is none.

'very pessimistic' and 7 is 'very optimistic'): Are you optimistic or pessimistic about the future of agriculture in this county?" In all counties the mean response of the key informants was toward the optimistic end of the spectrum, although the counties with higher levels of organizational development reported greater optimism for the future of agriculture in their county.

\section{Integrated Assessment of} Organizational and Policy Impacts

As a final step in our analysis, we estimated several multivariate models that seek to explain variation in indicators of the vitality of local agriculture and food systems using information about the level of social farm- and food-oriented organizational development, on the one hand, and the presence of key local agricultural development and food-system programs and policies on the other hand (see table 8)..$^{7}$ The results suggest that organizational develop-

\footnotetext{
${ }^{7}$ In each model, we control for basic differences in rural population density (in 2000), rates of population growth (1990-2000), and number of farms and volume of county farm
}

ment and local policies and programs can have statistically significant impacts on perceived policy impacts across our study counties. In other words, key informants in counties with advanced levels of organizational development and a wider array of specific agricultural development activities are more likely to feel that their community's efforts have kept land in farming, helped maintain the viability of local farms, and encouraged beginning farmers. One of the models examining factors related to average informants' optimism about the future of local agriculture in the county is not strongly related to level of organizational development, but was related to the existence of local agricultural development activities. Interestingly, moderate levels of organizational development (having either a local committee or a food policy council, but not both) and the presence of more specific local food systems activities were not associated with more positive perceptions of local policy impacts.

sales in 1997. Standardized regression coefficients for model variables and model fit statistics are reported in table 8 . 


\section{Discussion and Conclusions}

Our investigation of the relationship between agriculturally oriented community organizational development and the emergence of specific programs and policies to promote local agriculture reveals a number of interesting findings. First, it appears that organizational development has been greatest in the larger, more urbanized locales and in counties with a more dense agricultural landscape (i.e., more farms and total production). We also find a clear connection between organizational development and the existence of policies and programs that support agricultural businesses in general, as well as local food system development. This suggests that the facilitation of social organizational development (in the form of agricultural committees and food policy councils) may be important in creating a social infrastructure that is likely to generate and support the use of concrete policies, programs, and activities to support local farming and food systems. Social capital and social infrastructure have been found to be necessary ingredients in community development. Putnam (1993), Flora and Flora (1993), Sharp et al. (2002), Flora (1998), Green and Haines (2008) and this study support such an interpretation.

Subjective measures of the vitality of local agricultural systems were more positive in counties that had advanced organizational development and that had enacted more agricultural business-development policies and programs. Interestingly, local food-systems-oriented activities were not consistently related to informant perceptions of the local farm-sector conditions. Given the cross-sectional nature of our data (and the absence of information about how long such organizations and policies have been in place), we were unable to explore whether they have had the material impacts on trends in the farm sector that they were intended to create.

There are some limitations to this work. First, the data for this study, collected during one year from key informants, is not adequate to infer causal relationships between the variables. Another limitation is that it is not possible to directly assess the internal dynamics and degree of activity in local agriculturally oriented organizations. While a food policy council may exist in a community and its presence is associated with other local programs and policies, there is no way from the survey instrument to evaluate how well a food policy council functions or the intensity with which it carried out its work. In addition, we did not have adequate information to assess the extent to which these organizations and the various policies and processes were inclusive or supportive of the diversity of local agriculture and food-system stakeholders. Future qualitative studies of these organizations in AI and RUI counties will contribute to a better understanding of how organizational activities qualitatively vary and how these differences might influence patterns of local farming and food systems change.

This research has several implications for policy around local agriculture and food system development. Indeed, contrary to the belief in an "impermanence syndrome" (Berry, 1978) or the notion that farmers begin to make strategic decisions to disinvest in their operations due to the perception that urban pressures or competition will make the long-term future of local agriculture tenuous, we find that farmers and communities at the RUI are generally not responding to the potentially disempowering and homogenizing effects of urban pressures by simply allowing agriculture to fade away. Instead, our data reveal that many places are choosing to act by forming committees and food policy councils to support the viability of agriculture in their communities and implementing various programs and policies in order to develop a stronger, more vibrant local agriculture. This study finds that organizations such as committees to support the viability of agriculture and food policy councils are related to a community's ability to market local food, develop initiatives that increase the self-help capacity of the community, and increase farmers' participation within the local food system.

This research also offers strategic guidance to local leaders. For some, the idea that social development of the community may be a precondition or important factor in the ultimate success of achieving a 
particular programmatic or economic outcome may be surprising. But classic community-development theory, validated by these research findings, reveals that the development of the community (the community's organizational and social structures) qualitatively impacts developments in the community (such as particular projects and forms of economic activity). In fact, one member of this research team currently works for an alternative agricultural organization engaged in development work, and the lack of organizational capacity for food-system development is recognized as a clear limitation to the ambition of what can be proposed or pursued by some communities. This research has allowed that individual to think strategically about their work, and we anticipate that other practitioners might similarly benefit from the insights of this research.

\section{References}

Berry, D. (1978). Effects of urbanization on agricultural activities. Growth and Change. 9, 2-8. http://dx.doi.org/10.1111/j.14682257.1978.tb01024.x

Blakely, E. (1994). Planning local cconomic development: Theory and practice, $2^{\text {nd }}$ ed. Thousand Oaks, CA: Sage Publications.

Clancy, K., Hammer, J., \& Lippoldt, D. (2007). Food Policy Councils. In C. C. Hinrichs \& T. A. Lyson (Eds.), Remaking the North American food system: Strategies for sustainability (pp. 121-143). Lincoln, NE: University of Nebraska Press.

Christensen, J. A., Fendley, K., \& Robinson, J. W. (1989). Community development. In J. A. Christenson \& J. W. Robinson Jr. (Eds.), Community development in perspective (pp. 3-25). Ames, IA: Iowa State University Press.

Clark, J. K. (2009). The repositioning of farming in newly restructured, consumptive spaces: The relational geography of U.S. peri-urban agriculture (Unpublished doctoral dissertation). Columbus, $\mathrm{OH}$ : Ohio State University.

Clark, J. K., Inwood, S., Sharp, J. S., \& Jackson-Smith, D. (2010). Community-level influences on agricultural trajectories: Seven cases across the exurban U. S. In R. G. Winchell, D. Ramsey, R. Koster, \& G. M. Robinson (Eds.), Sustainable rural community change: Geographical perspectives from North America, the British Isles, and Australia (pp. 200-210). Brandon, Manitoba: Rural Development Institute.
Cowan, T. (2002). Value-added agricultural enterprises in rural development strategies (Congressional Research Service Report RL31598). Washington, DC: Congressional Research Service.

Dillman, D. A. (2007). Mail and Internet surveys: The tailored design method. Hoboken, NJ: John Wiley \& Sons.

Feenstra, G. (2002). Creating space for sustainable food systems: Lessons from the field. Agriculture and Human Values. 19, 99-106. http://dx.doi.org/10.1023/A:1016095421310

Flora, J. L. (1998). Social capital and communities of place. Rural Sociology 63(4), 481-506. http://dx.doi.org/10.1111/j.15490831.1998.tb00689.x

Flora, C. B., \& Flora, J. L. (2004). Rural communities: Legacy and change. $2^{\text {nd }}$ ed. Boulder, CO: Westview Press.

Flora, C. B., \& Flora, J. L. (1993, September). Entrepreneurial social infrastructure: A necessary ingredient. ANN ALS, AAPSS, pp. 48-58.

Garkovich, L. (1989). Local organizations and leadership in community development. In J. A. Christensen \& J. W. Robinson Jr. (Eds.), Community development in perspective. Ames, IA: Iowa State University Press.

Goldschmidt, W. (1978). As you sow. Glencoe, IL: The Free Press.

Green, G. P., \& Haines, A. (2008). Asset building and community development. $2^{\text {nd }}$ ed. Los Angeles, CA: Sage Publications.

Hinrichs, C. C., \& Lyson, T. A. (Eds.). (2007). Remaking the North American food system: Strategies for sustainability. Lincoln, NE: University of Nebraska Press.

Jackson-Smith, D., \& Jensen, E. (2009). Agricultural importance versus farm dependence: A new typology. Rural Sociology, 74(1), 37-55. http://dx.doi.org/10.1526/003601109787524016

Jackson-Smith, D., \& Sharp, J. (2008). Farming in the urban shadow: Supporting agriculture at the ruralurban interface. Rural Realities, 2(4):1-12.

Korsching, P. F., \& Allen, J. C. (2004). Local entrepreneurship: A development model based on community interaction field theory. The Journal of the Community Development Society, 35(1), 25-43. http://dx.doi.org/10.1080/15575330409490120

Krannich, R. S., \& Humphrey, C. R. (1986). Using key informant data in comparative community research. Sociological Methods and Research, 14(4), 473-493. http://dx.doi.org/10.1177/0049124186014004006 
Littrell, D. W., \& Hobbs, D. (1989). The self-help approach. In J. A. Christenson \& J. W. Robinson Jr. (Eds.), Community development in perspective. Ames, IA: Iowa State University Press.

Lobao, L., \& Stofferahn, C. W. (2008). The community effects of industrialized farming: Social science research and challenges to corporate farming laws. Agriculture and Human V alues, 25(2), 219-240. http://dx.doi.org/10.1007/s10460-007-9107-8

Lyson, T. (2004). Civic agriculture: Reconnecting farm, food, and community. Medford, MA: Tufts University Press.

Lyson, T. (2007). Civic agriculture and the North American food system. In C. C. Hinrichs \& T. A. Lyson (Eds.), Remaking the North American food system: Strategies for sustainability (pp. 19-32). Lincoln, NE: University of Nebraska Press.

Muske, G., \& Woods, M. (2004). Micro business as an economic development tool: What they bring and what they need. Journal of the Community Development Society, 35(1), 97-116. http://dx.doi.org/10.1080/15575330409490124

Muske, G., Woods, M., Swinney, J., \& Khoo, C. L. (2007). Small businesses and the community: Their role and importance within a state's economy. Journal of Extension, 45(1). Available at http://www.joe.org/joe/2007february/rb4.php

Nelson, B., Mullan, C., O’Neill, J., \& Morse, D. E. (2004). Resources for beginning farmers: Building a sustainable future (MISA Report). St. Paul, MN: Minnesota Institute for Sustainable Agriculture.

Porreca, L., (2010). The influence of collective action and policy in the development of local food systems (Unpublished doctoral dissertation). Logan, Utah: Utah State University.

Preston, K., \& Bailey, J. M. (2007). Promising opportunities: A fresh look at opportunities for rural communities (Center for Rural Affairs Report). Retrieved from http://www.cfra.org/ files/Promising $\% 200$ pportunities.pdf

Putnam, R. D. (1993, March 21). The prosperous community: Social capital and public life. The American Prospect. Retrieved from http://www.prospect.org/cs/articles?article= the prosperous community

Sharp, J. S. (2001). Locating the community field: A study of interorganizational network structure and capacity for community action. Rural Sociology, 66(3), 403-424. http://dx.doi.org/10.1111/i.15490831.2001.tb00074.x

Sharp, J. S., Agnitsch, K., Ryan, V., \& Flora, J. (2002). Social infrastructure and community economic development strategies: The case of selfdevelopment and industrial recruitment in rural Iowa. Journal of Rural Studies, 18(4), 405-417. http://dx.doi.org/10.1016/S0743-0167(02)00011-6

Sharp, J. S, Clark, J. K., Davis, G. A., Smith, M. B., \& McCutcheon, J. S. (2011). Adapting community and economic development tools to the study of local foods: The case of Knox County, OH. Journal of Extension, 49(2). Available at http://www.joe.org/joe/2011april/a4.php

Sharp, J. S, \& Smith, M. B. (2004). Farm operator adjustments and neighboring at the rural-urban interface. Journal of Sustainable Agriculture, 23(4), 111131. http://dx.doi.org/10.1300/J064v23n04 09

Thomas, J. K., \& Howell, F. M. (2003). Metropolitan proximity and U.S. agricultural productivity, 19781997. Rural Sociology, 68(3), 366-386. http://dx.doi.org/10.1111/j.15490831.2003.tb00142.x

U.S. Bureau of the Census. (1992). Census of population and housing 1990: Summary Tape File 3A: CDROM. Washington, DC: The Bureau of the Census.

U.S. Bureau of the Census. (2002.) Census of population and housing, 2000: Summary Tape File 3A: CDROM. Washington, DC: The Bureau of the Census.

U.S. Department of Agriculture, National Agricultural Statistics Service. (2004). Census of Agriculture CD-ROM. Washington, DC: USDA, National Agricultural Statistics Service.

U.S. Department of Agriculture, National Agricultural Statistics Service. (2009.) Census of agriculture. Accessed online at http://www.agcensus.usda.gov/Publications/2007 /Full_Report/index.asp

Wilkinson, K. (1970, March). The community as a social field. Social Forces, 48, 311-322. http://dx.doi.org/10.2307/2574650

Wilkinson, K. (1972). A field-theory perspective for community development research. Rural Sociology, 37(1), 43-52.

Woolcock, M. (1998). Social capital and economic development: Toward a theoretical synthesis and policy framework. Theory and Society, 27, 151-208. http://dx.doi.org/10.1023/A:1006884930135

Wright, W., Score, M., \& Conner, D. S. (2007). Food system makers: Motivational frames for catalyzing agri-food development through multi-stakeholder collaboration. Journal of the Community Development Society, 38(3), 47-59. 